\title{
TIPOLOGIAS BÍBLICAS
}

Edson José Lira Turiano ${ }^{1}$

\section{RESUMO}

A Tipologia é uma das áreas mais importantes do estudo bíblico, por sua riqueza de conteúdo e ensinamentos para a igreja. Entretanto, poucos cristãos aprofundam-se neste vasto campo dos tipos bíblicos. Talvez isto se dê por causa da especulação fantasiosa de alguns, que exageram na imaginação e criatividade quanto aos tipos bíblicos ou ainda pelo secularismo que tenta desacreditar o fator sobrenatural das Escrituras Sagradas. Apesar disto, a Tipologia Bíblica continua sendo um excelente auxílio na compreensão do plano redentor divino e no conhecimento de nosso Senhor Jesus Cristo. Disse um antigo escritor: "Através dos tipos, na dispensação passada, Deus estava ensinando aos seus filhos as letras. Nesta dispensação Ele está ensinando como juntar as letras, as quais organizadas como eles querem, soletram Cristo, e nada mais que Cristo".

Palavras-Chave: Tipologia Bíblica; Estudo Bíblico; Cristo

\section{INTRODUÇÃO}

O apóstolo Paulo afirma, em Rm 15.4: "Porque tudo que dantes foi escrito para nosso ensino foi escrito, para que, pela paciência e consolação das Escrituras, tenhamos esperança." Ele estava dizendo que tudo o que foi escrito tinha a finalidade de trazer algum ensinamento para a igreja. Isto nos ajuda a entender que, algumas passagens bíblicas que falam de leis e rituais, por exemplo, que não são mais aplicados à igreja do Novo Testamento, possuem um ensinamento válido para os nossos dias. Eles eram mandamentos para o povo de Israel, durante a dispensação da Lei, mas também apresentam verdades ético-espirituais e princípios relevantes, cujo significado apontava para coisas que haveriam de vir.

A Tipologia Bíblica é uma área de estudo da Hermenêutica, e utiliza o método histórico-gramatical, isto é, o princípio de interpretação literal ou textual da Bíblia, utilizado de forma sistemática, o qual permite que a própria Escritura interprete a si mesma, através da progressão da revelação, sem fantasias e simbolismos complexos. Não devemos, portanto, confundir o estudo dos tipos com o método alegórico de interpretação da Bíblia, o qual

\footnotetext{
${ }^{1}$ Doutor em Ciências da Religião - FICS - Facultad Interamericana de Ciencias Sociales

E-mail: eturianolira@yahoo.com.br
} 
pretende dar ao texto um significado que ele não possui. Sobre este assunto, Charles Ryrie $^{1}$ afirma:

Os dispensacionalistas reclamam para si a interpretação literal na hermenêutica. Isso significa uma interpretação que dá o mesmo significado a toda palavra que teria em seu uso normal, quer empregado na escrita, fala ou no pensamento. Às vezes é chamado de interpretação histórica gramatical, pois o significado de cada palavra é determinado por considerações históricas e gramaticais. O princípio pode também ser chamado de interpretação normal, pois o significado literal das palavras é a abordagem normal para o seu entendimento em todas as línguas. Pode ser designado também de interpretação simples, já que ninguém recebe a idéia errada de que o princípio literal elimine o uso de figuras de linguagem. Símbolos, figuras de linguagem e tipos são todos interpretados de maneira simples neste método, e não são contrários à interpretação literal. Afinal de contas, a existência de uma figura de linguagem depende da realidade do significado literal dos termos usados. Muitas vezes as figuras tornam mais claro o significado literal, normal e simples que elas transmitem ao leitor".

\section{DESENVOLVIMENTO}

\section{Tipologias Bíblicas}

O estudo dos tipos é uma das áreas mais ricas da teologia bíblica, não apenas pela riqueza de detalhes e significados que ela apresenta, mas porque apresenta o caráter sobrenatural da revelação divina, através da Bíblia Sagrada, quando demonstra a apresentação de verdades tratadas no Novo Testamento, através de personagens e objetos descritos no Antigo Testamento, mostrando que, somente o Espírito Santo, que conduziu o processo de produção do texto sagrado, poderia construir uma relação tão perfeita e tão fora do alcance dos que viveram nos tempos vetero-testamentários. A respeito desta relação declarou o Pr. Luiz Sayão:

Um dos assuntos que merece reflexão aprofundada no contexto atual da igreja evangélica brasileira é a relação entre Antigo e Novo Testamentos. A questão por si só já é um grande desafio hermenêutico. Em função do aspecto ainda pueril da igreja e da teologia brasileira, a questão torna-se ainda mais relevante.

Entre as questões mais fascinantes dessa relação entre os dois testamentos está a questão da tipologia. Trata-se do estudo criterioso de como Cristo e sua obra são prefigurados no Antigo Testamento. Na verdade tal tarefa não é nada simples. Discorrendo sobre a importância do tema, Ada Habershon afirma:

Nosso Senhor tinha os tipos em alta estima. Repetidas vezes se referia a eles e demonstrava como apontavam para ele mesmo. Que estudo bíblico maravilhoso 
deve ter dado àqueles dois discípulos no caminho de Emaús, quando "começando por Moisés e todos os profetas, explicou-lhes o que constava a respeito dele em todas as Escrituras"; e pelas mesmas Escrituras responde à sua própria pergunta: "não devia o Cristo sofrer estas coisas, para entrar na sua glória?". Os sofrimentos e a glória foram preditos nos tipos, tanto quanto nas profecias diretas; e não era de se admirar que o coração ardia dentro deles naquela caminhada memorável, e, mais tarde, ao anoitecer, quando "lhes abriu o entendimento para que pudessem compreender as Escrituras". Os eventos que tinham acabado de acontecer, estavam todos prefigurados nas Escrituras; mas não tinham compreendido os antigos textos familiares até Jesus lhes mostrar como era "necessário que se cumprisse tudo a respeito [de Jesus] estava escrito na Lei de Moisés, nos Profetas e nos Salmos". Aqueles que negligenciam o estudo dos tipos, deixam de perceber o quanto de Cristo se acha na Lei de Moisés".

Há certa divergência entre os estudiosos das regras de interpretação bíblica, no tocante aos tipos, indo desde a exigência de uma declaração explícita dos tipos no NT, até a completa negação do significado deles. A respeito desta divergência, Roy Zuckexplica:

\begin{abstract}
Os intérpretes da Bíblia, contudo, possuem opiniões muito divergentes no tocante à ocorrência dos tipos nas Escrituras. Alguns dizem que estes se evidenciam em quase todo o Antigo Testamento. Afirma-se que inúmeros elementos e acontecimentos retratam verdades neotestamentárias. Por exemplo, diz-se que as dobradiças da porta do Templo de Salomão representam as duas naturezas de Cristo. Outros sustentam que os tipos ou estão explicitamente identificados no Novo testamento, ou encontram-se implícitos. Alguns estudiosos da Bíblia acreditam que tipos são aqueles que o Novo Testamento assim identifica, ou seja, aqueles que se afirma explicitamente serem tipos. Outros ainda entendem que não existe tipologia na Bíblia

O Novo Testamento nos dá a exposição doutrinária dos tipos. Declarações abstratas da verdade são muito mais fáceis de serem compreendidas através de algumas representações visíveis, como as usadas no Tabernáculo. Assim, o Tabernáculo é repleto de tipos ilustrativos. Tipos, como já dissemos, são sombras, e sombras envolvem substâncias. Todos esses elementos são lições objetivas, símbolos materiais para expressar verdades espirituais".
\end{abstract}

Além disto, ajuda a estabelecer uma ligação perfeita entre o Antigo e o Novo Testamento, ressaltando a unidade das Escrituras e sua inspiração divina e sobrenatural, apresentando a pessoa de Cristo como o centro da Palavra de Deus. Sobre este aspecto divino do estudo dos tipos, Roy Zuck destaca:

\begin{abstract}
Uma das vantagens é que nos permite enxergar o traçado divino da história, pelo fato de ele escolher pessoas, acontecimentos e elementos de Israel para retratar e predizer aspecto de Cristo e de seu relacionamento com os crentes de hoje. Enxergar essas relações tipo - antítipo ajuda-nos a ver a mão de Deus na história
\end{abstract}

\title{
O Que é Tipologia Bíblica?
}

É o estudo das figuras e símbolos da Bíblia, com os quais Deus procura mostrar, por meio de coisas terrestres, as coisas espirituais. Visto a incapacidade da mente humana de 
compreender as coisas divinas, nos mesmos termos encontramos no Antigo Testamento Deus falando das glórias celestiais através de coisas terrestres.

A interpretação das profecias depende da significação dos símbolos. Por meio de símbolos, o Velho Testamento contém as doutrinas do Novo. A tipologia baseia-se na suposição de que há um padrão na obra de Deus através da história da salvação. Deus prefigurou sua obra redentora no Antigo Testamento e a cumpriu no Novo; o Antigo Testamento contém sombras de coisas que seriam reveladas de modo mais pleno no Novo. Como disse Agostinho: "O Novo está contido no Velho e o Velho explica o Novo".

O tipo bíblico é uma representação real pré-ordenada, pela qual pessoas, eventos e instituições do Antigo Testamento prefiguram pessoas, eventos e instituições do Novo Testamento. São figuras, ou lições, pelas quais Deus tem ensinado seu povo acerca do seu plano redentor e de seus elevados propósitos para a vida cristã.

Os tipos se baseiam em linguagem figurada, como as alegorias e parábolas, com uma diferença: na alegoria, assim como na parábola, a narrativa tem a finalidade de ilustrar uma verdade maior que se deseja transmitir, sem a necessidade de ser o registro fiel de algum fato passado. O tipo, entretanto, é um fato histórico, apresentado exatamente como aconteceu, mas que possui uma mensagem profética.

A prefiguração é chamada TIPO e o cumprimento é chamado ANTÍTIPO. O tipo é o objeto da lição, a revelação temporária de uma pessoa, um acontecimento ou uma instituição vindoura. $\mathrm{O}$ antítipo é o cumprimento daquilo que havia sido predito.

\section{Termos Bíblicos}

Existem algumas palavras no grego do Novo Testamento utilizadas para fazer referência aos tipos:

1. O termo tipo vem da palavra typos, que é traduzido como figura, e aparece em Rm 5.14; 1 Cor 10.6,11.

2. A palavra skia, traduzida como sombra, que aparece em $\mathrm{Cl} 2.17$ e $\mathrm{Hb} 10.1$.

3. A palavra upodeigma, traduzida como figura, como em $\mathrm{Hb} 9.23$.

4. A palavra parabole, traduzida como parábola ou alegoria, que aparece em $\mathrm{Hb}$ 9.9.

5. A palavra antitypos, traduzida como figura em Hb. 9.24 e 1Pe 3.21.

\section{Classificação Dos Tipos}


Embora algumas variações de menor importância com referência ao número e nomes das várias classes de tipos, apresentamos a seguir um modo rápido de classificar os tipos:

\section{Tipos Históricos}

1. Pessoais: quando certos personagens do Velho Testamento têm alguma semelhança com a pessoa de Jesus Cristo ou ilustram alguma revelação da doutrina do Evangelho.

2. Coletivos: aplicação dos acontecimentos da vida dum povo ou duma coletividade à Igreja aqui no mundo ou como sinalização para o modo de proceder dos crentes. Alguns objetos e animais do Antigo Testamento são inseridos nesta classe porque só possuem significado tipológico quando inseridos no evento que envolve a coletividade de Israel, como por exemplo, a rocha de Horebe, que não é tipo por ser uma rocha, mas pela situação que foi criada com o povo.

\section{Tipos Rituais}

1. Quando os detalhes da Lei Mosaica prefiguram o ensino do Novo Testamento. Aqui estão inseridos os rituais e festas do povo judeu e os aspectos relacionados ao Tabernáculo e o sacerdócio.

\section{TIPO X SÍMBOLO}

Os tipos assemelham-se aos símbolos e podem até ser considerados uma espécie particular de símbolo. Entretanto, duas características os diferenciam:

1. Os símbolos servem de sinais de algo que representam sem necessariamente ser semelhantes em qualquer respeito. Podemos citar como exemplo o vento e o fogo, símbolos do Espírito Santo, que também matam e destroem.

2. Os tipos apontam para o futuro, enquanto os símbolos podem não fazê-lo. Um tipo sempre precede historicamente o seu antítipo, ao passo que um símbolo pode preceder, coexistir, ou vir depois daquilo que ele simboliza. Um exemplo disto é a pomba, símbolo do Espírito Santo, que continua existindo mesmo depois da descida do Espírito Santo.

\section{Tipos Históricos Pessoais}


Também chamados de Tipos Humanos, os tipos pessoais consistem em personagens do Antigo Testamento. Deus usou detalhes das suas vidas, características suas, eventos nos quais foram envolvidos e o seu caráter, para profetizar a respeito de Jesus Cristo. São pessoas cujas vidas e obras são uma verdadeira profecia, com a qual podemos aprender sobre a vida e obra de Jesus.

É importante observar que cada tipo é insuficiente e incapaz de representar sozinho o todo a respeito de Jesus Cristo.

Quando, porém, estudamos o conjunto de personagens tipológicos, percebemos que cada uma vai acrescentar mais detalhes a esta apresentação tipológica. Davi destaca o reinado, Melquisedeque, o sacerdócio, Isaque, o filho e noivo, Moisés, o líder e libertador, José, a humilhação e exaltação, e assim por diante. Aprendemos com todos a respeito do grande antítipo: Cristo.

\section{a) Moisés}

Moisés ocupa um lugar destacado entre os personagens do Antigo Testamento, não apenas por ter sido o libertador e legislador de Israel, mas, também, pelo relacionamento tipológico com Cristo. São muitas as semelhanças encontradas entre Jesus e Moisés, tanto na vida, quanto na obra de ambos. Além disto, a Bíblia declara haver uma relação profética muito explícita entre eles.

Moisés declarou que Deus levantaria, no futuro, um profeta também judeu, cuja vida seria semelhante à sua. Para ter a certeza de que este seria o profeta levantado por Deus, os judeus deveriam verificar se a sua vida era semelhante à de Moisés. Ele assim declarou: "O SENHOR, teu Deus, te despertará um profeta do meio de ti, de teus irmãos, como eu; a ele ouvireis" (Dt 18.15).

Quando João Batista apareceu, acharam que ele poderia ser este profeta, então lhe perguntaram: "És tu o profeta?" (Jo 1.21). Quando, porém o povo viu Jesus realizando o milagre da multiplicação dos pães, afirmaram: "Este é, verdadeiramente, o profeta que devia vir ao mundo" (Jo 6.14). Declaração semelhante foi feita por Felipe, ao dirigir-se a Natanael, a respeito de Jesus: "Havemos achado aquele de quem Moisés escreveu na Lei e de quem escreveram os Profetas: Jesus de Nazaré, filho de José” (Jo 1.45), e por Estevão, em seu discurso: "Este é aquele Moisés que disse aos filhos de Israel: O Senhor vosso Deus vos levantará dentre vossos irmãos um profeta como eu; a ele ouvireis" (Jo 7.37).

Grant Jeffrey, apresenta muitas semelhanças entre Jesus e Moisés: 
A vida de Jesus foi similar à de Moisés: ambos foram profetas, sacerdotes, legisladores, mestres, líderes de homens. Ambos ensinaram novas verdades de Deus e confirmaram seus ensinos com milagres. Ambos passaram seus primeiros anos de vida no Egito, miraculosamente protegidos daqueles que procuravam tirar suas vidas. A família de Moisés, inicialmente, não aceitava sua função. Entretanto, mais tarde seu irmão Arão e sua irmã Miriã o ajudaram. A mãe de Jesus, seus irmãos e suas irmãs inicialmente erraram em não seguí-lo. No entanto, mais tarde seu irmão Tiago tornou-se um dos líderes da igreja em Jerusalém.

Cada um deles foi considerado o homem mais sábio de seus dias. Ambos confrontaram poderes demoníacos e os subjugaram com sucesso. Assim como Moisés determinou setenta juízes sobre Israel, Jesus ungiu setenta discípulos para ensinar as nações. Moisés enviou doze espias para Canaã; Jesus enviou doze apóstolos para alcançar o mundo. A Bíblia não diz que algum deles tenha experimentado alguma doença. E os corpos de ambos não permaneceram em seus túmulos. Ambos jejuaram quarenta dias e experimentaram crises espirituais no topo de montes. Assim como Moisés estendeu a sua mão sobre o Mar Vermelho para exercer autoridade sobre ele, Jesus repreendeu o Mar da Galiléia e aquietou as suas ondas. As faces de ambos brilharam com a glória dos céus, Moisés no monte Sinai e Jesus no monte da transfiguração.

Moisés resgatou Israel de sua religiosidade morta no Egito pagão; Jesus resgatou Israel da letra morta e da tradição da Lei. Moisés e Jesus curaram leprosos e provaram sua autoridade através de milagres, os quais fizeram diante de muitos. Assim como Moisés teve vitória sobre o grande inimigo de Israel, os amalequitas, com seus braços levantados, Jesus teve vitória sobre os nossos grandes inimigos, o pecado e a morte, ao levantar seus braços na cruz. Moisés levantou a serpente de bronze no deserto, a fim de curar as pessoas; Jesus foi levantado na cruz para curar dos pecados a todos aqueles que creem.

O povo foi ingrato e se rebelou contra a liderança de ambos. As gerações que se rebelaram contra eles morreram por falta de fé: uma no deserto, e a outra, no cerco de Jerusalém em 70 d.C. Moisés e Jesus morreram num monte. Moisés prometeu que outro profeta viria; Jesus prometeu à Igreja que seu Pai enviaria outro "consolador", o Espírito Santo.

No Mês de Nisã, no décimo-quarto dia, que era a festa da Páscoa, tanto Moisés quanto Jesus libertaram aqueles que neles creram. No septuagésimo dia, na festa das Primícias, Moisés trouxe a ressurreição para os filhos de Israel quando passaram pelo Mar Vermelho; na mesma data Jesus trouxe as primícias da ressurreição, quando levantou dentre os mortos. Cinquenta dias mais tarde, na festa de Pentecostes, Deus concedeu um grande presente a Israel e a todas as nações, dando-lhes a Torá, a Lei. Cinquenta dias após a ressurreição de Jesus, Deus deu à Igreja o grande Dom do batismo do Espírito Santo”. 


\title{
b) Davi
}

O rei Davi também merece destaque, entre os personagens de Israel, pelo aspecto profético e tipológico que apresenta. Sendo pastor de ovelhas, rei de Israel, nascido em Belém de Judá, ele possui muitas semelhanças com o Senhor Jesus. A promessa feita a Israel, a respeito de um rei, que Deus levantaria, no futuro, sobre o seu povo, é descrita por Ezequiel: "E suscitarei sobre elas um só pastor, e ele as apascentará; o meu servo Davi é que as apascentará; ele lhes servirá de pastor. E eu, o SENHOR, lhes serei por Deus, e o meu servo Davi será príncipe no meio delas; eu, o SENHOR, o disse" (Ez 34.23,24), é ratificada na fala do anjo Gabriel a Maria, falando a respeito de Jesus: "e o Senhor Deus lhe dará o trono de Davi, seu pai" (Lc 1.32).

A respeito das características tipológicas de Davi, afirma Groningen:

\begin{abstract}
Israel recebeu um rei segundo o coração de Deus, que provou ser um governante compassivo, um administrador efetivo, um líder destemido contra os inimigos de Yahweh e de seu povo. Além disto, repetidas vezes o julgamento de Deus foi executado. Esses julgamentos foram antecipações do julgamento que veio sobre Israel no exílio, na dispersão, e do julgamento final que virá sobre toda e quaisquer pessoas descrentes e desobedientes de todas as terras e nações. Finalmente, esse período prepara a cena para o reino messiânico típico de Davi, o "Leão" de Judá (cf. Ap 5.5), o governador prometido que haveria de ter o cetro de realeza (Gn 49.8-12), da semente de Abraão (Gn 15.17) e da linha de Sem (Gn 9.27). Ele foi o homem que seria mais semelhante ao Adão real como Deus o criou, do que qualquer outra pessoa, exceto seu antítipo, Jesus Cristo.
\end{abstract}

\section{c) Melquisedeque}

Melquisedeque é uma figura muito enigmática. Há quem ache que se tratava do próprio Sem, filho de Noé, visto que o mesmo viveu por 600 anos, isto é, tempo suficiente para estar vivo na época de Abraão. A Bíblia, entretanto, afirma que ele era "sem pai, sem mãe, sem genealogia, não tendo princípio de dias nem fim de vida, mas sendo feito semelhante ao Filho de Deus" (Hb 7.3). Isto significa que não sabemos a sua origem, nem destino. O escritor aos Hebreus indica que isto era uma representação da eternidade de Cristo e de seu sacerdócio.

Jesus não poderia ser sacerdote da linhagem levítica, pois era da tribo de Judá. Assim sendo, seu sacerdócio é representado pelo de Melquisedeque: rei e sacerdote, de uma linhagem superior à de Levi, visto que Abraão, ascendente de Levi, o reconhece como superior.

\section{d) José}

Há certa polêmica envolvendo a pessoa de José, como sendo um tipo de Cristo. Ele apresenta muitas semelhanças com a pessoa de Cristo. Sua vida apresenta muita similaridade com o ministério de Cristo. Desde o fato de ser rejeitado pelos irmãos e amado pelo pai, ter sido vendido pelos que lhe eram chegados, e sua humilhação, na casa de Potifar e no cárcere, 
ainda que mantendo a integridade, até a exaltação e poder no Egito, apontam para e humilhação e glorificação de Cristo. Ada Habershon afirma, a respeito de José:

\begin{abstract}
Os treze capítulos que narram a bela história da vida de José estão repletos de Cristo. À medida que um versículo atrás do outro apresenta o conhecido quadro do AT, podemos comparar com eles muitas passagens do NT que descrevem a vida e o caráter daquele que José tipifica tão maravilhosamente. É amado por seu pai, vestido por ele e enviado numa missão para seus irmãos. É odiado e invejado por eles, que lhe recusam lealdade, conspiram contra ele, despojam-no de suas roupas e o entregam nas mãos dos gentios. As tristezas, os sofrimentos e a vergonha pelos quais passou são retratados numa série de quadros. A cova, o preço da compra, a casa de Potifar e o cárcere mostram como José foi levado, passo a passo, pelo caminho da humilhação abaixo. A cova nos lembra o clamor do Senhor no Salmo 69: "nas profundezas lamacentas eu me afundo; não tenho onde firmar os pés [...] nem deixes que a cova feche sobre mim a sua boca!" (v. 2.15). Quando José foi vendido como escravo, o preço que se pagou por ele foi trinta moedas de prata. De forma semelhante, o Senhor Jesus foi traído por trinta moedas de prata, o preço de um escravo (Ex 21.32). Em seguida, José se torna servo na casa de Potifar, capitão da guarda. Semelhantemente a Jesus, de quem lemos em Is 49.7,8: "aquele que foi desprezado e detestado pela nação [...] servo de governantes.
\end{abstract}

A dificuldade, porém, de muitos é gerada pelo fato de não encontrarmos uma declaração explícita da relação tipológica de José com Cristo, no Novo Testamento. Apesar das questões relacionadas a tempo, semelhança e elevação serem satisfeitas, muitos sentem falta de uma evidência bíblica declarada.

\title{
e) Isaque
}

Isaque possui características semelhantes a José, no que tocante à tipologia: muitas semelhanças e pouca evidência. Isaque era filho de Abraão, chamado por Deus de "único filho" (Gn 22.2, 12,16), apesar da existência de Ismael. O fato de ter uma noiva, a qual foi preparada e trazida de uma terra distante por um enviado de seu pai, já aponta para a relação entre Cristo e a Igreja. O evento mais significativo, porém, no aspecto tipológico, é o que ocorreu no Monte Moriá, quando, a pedido de Deus, Abraão o coloca em um altar, com a finalidade de oferece-lo em sacrifício.

\section{Tipos Históricos Coletivos}

São chamados também de Tipos Não-humanos. Em geral, são objetos e eventos, registrados no Antigo Testamento, os quais Deus usou para apresentar características de seu filho, Jesus Cristo. Os tipos são chamados de coletivos, porque são apresentados em um evento que envolve a coletividade de Israel. Assim sendo, o tipo é marcado não apenas por suas próprias características, mas pela ocasião nas quais elas se apresentam.

O cordeiro, por exemplo, não é declarado como sendo um tipo apenas por suas características, mas por causa dos eventos que envolvem a Páscoa e seu significado. O que vai caracterizar a relação tipológica não é apenas a figura do cordeiro, mas o cordeiro 
sacrificado na Páscoa, cujo significado estará associado a detalhes como local, data, pessoas envolvidas e finalidade do evento. De igual modo, a Rocha de Horebe e a Serpente de Bronze, entre outros, têm sua relação tipológica apresentada durante os eventos nos quais estão inseridos.

\section{a) O Cordeiro Pascoal}

A relação tipológica do cordeiro pascoal com Cristo é uma das mais belas e completas, dentre os tipos coletivos. A relação do Senhor Jesus Cristo com o cordeiro, é apresentada no Novo Testamento, em muitas passagens. João Batista afirma que ele é "o Cordeiro de Deus, que tira o pecado do mundo" (Jo 1.29); o livro do Apocalipse o apresenta como tal, muitas vezes (Ap 5.6,8,12,13; 6.1,16; 7.9,10,14; 12.11; 13.8; 14.1, entre outras); o apóstolo João faz referência ao cordeiro, quando aplica a Cristo a profecia que dizia: "Nenhum dos seus ossos será quebrado" (Jo 19.36); o apóstolo Pedro faz referência ao "o precioso sangue de Cristo, como de um cordeiro imaculado e incontaminado" (1Pe 1.19). É o apóstolo Paulo, porém, que apresenta a declaração tipológica mais explícita, quando afiram: "Porque Cristo, nossa páscoa, foi sacrificado por nós" (1Cor 5.7), numa alusão direta à correspondência entre tipo e antítipo.

Muitas são as semelhanças apresentadas pelo cordeiro da Páscoa, com relação a Cristo:

1. O cordeiro deveria ser macho, de um ano (Ex 12.5), uma referência à idade adulta de Cristo em seu ministério terreno;

2. Não poderia possuir defeitos ou manchas (Ex 12.5), indicando a condição de Jesus sem pecados ( $\mathrm{Hb} 4.15)$;

3. O cordeiro deveria ser guardado desde o décimo dia (Ex 12.3,6), uma referência ao que Pedro afirmou sobre Cristo: "conhecido, ainda antes da fundação do mundo, mas manifestado nestes últimos tempos" (1 Pe 1.20);

4. O cordeiro deveria ser sacrificado ao décimo quarto dia, ao cair da tarde (Ex 12.6), uma referência ao momento da morte de Cristo, no Calvário (Jo 19.14);

5. O sacrifício deveria ser feito por toda a congregação (Ex 12.6), demonstrando o caráter universal do sacrifício de Cristo;

6. O sangue do cordeiro deveria ser aspergido, nas portas e isto seria o sinal para a libertação (Ex 12.7), uma referência à redenção através do sangue de Cristo (Ap 5.9,10);

7. A carne do cordeiro deveria ser assada no fogo (Ex 12.8,9), o que indica o juízo divino executado na pessoa de Cristo (2 Cor 5.21);

8. Nenhum osso do cordeiro deveria ser quebrado (Ex 12.46), o que foi uma profecia concernente a Cristo (Jo 19.36); 
9. O cordeiro deveria ser sacrificado em lugar do primogênito, isto é, um sacrifício substitutivo, uma alusão ao sacrifício vicário de Cristo (Is 53.4-6).

\section{b) A Rocha de Horebe}

O apóstolo Paulo apresenta a evidência bíblica da relação tipológica da rocha com Cristo, quando afirma: "E beberam todos de uma mesma bebida espiritual, porque bebiam da pedra espiritual que os seguia; e a pedra era Cristo" (1 Cor 10.4). Ele mostra que Cristo, ao ser ferido, trouxe o refrigério e vida para todos, assim como ocorreu com a rocha, em Horebe. Joel Leitão apresenta esta relação tipológica nos seguintes termos:

A rocha é o tipo de Jesus Cristo, que foi ferido pelo juízo de Deus para nos dar a água da vida: "mas aquele que beber da água que eu lhe der nunca terá sede..." (Jo 4.14a). Moisés executou a ordem de Deus e a água saiu da rocha ferida. "E beberam todos de uma mesma bebida espiritual, porque bebiam da pedra espiritual que os seguia; e a pedra era Cristo" (1Cor 10.4).

\section{c) A Serpente de Bronze}

Partindo do Monte Hor, rodeando a terra dos edomitas, o povo de Israel comete grande pecado contra o Senhor ao murmurar reclamando da comida e fazendo referência ao maná, enviado por Deus todos os dias, dizendo: "a nossa alma tem fastio deste pão tão vil" (Nm 21.5). Por sua rebeldia, Deus os castiga enviando serpentes ardentes ou abrasadoras, as quais trouxeram a morte a muitos.

Arrependidos do seu pecado o povo pede a Moisés que interceda por eles a Deus, para que ele retire as serpentes. Como solução para o problema, Deus ordenou: "Faze uma serpente ardente e põe-na sobre uma haste; e será que viverá todo mordido que olhar para ela" (Nm 21.8).

Deus estava usando a figura daquilo que trouxe a morte para trazer a vida. De igual modo, ele nos mandou Cristo, para ser morto, a fim de manifestar a vida de Deus para nós. Cada israelita que fosse picado por uma serpente deveria olhar para a figura da serpente, para que vivesse. De nada adiantaria olhar para si, para a serpente, para a ferida ou para os que estavam ao seu redor.

\section{Tipos Rituais}

Os objetos e rituais da lei mosaica, assim como os que lidavam com eles, foram dados não apenas como uma regra de culto e de relacionamento com Deus, mas também como uma mensagem profética, que apontava para Cristo. O escritor aos Hebreus afirma, a respeito deles: "Os quais servem de exemplo e sombra das coisas celestiais" (Hb 8.5). 
Muito poderia ser estudado a respeito de cada sacrifício, ritual ou festa. Neste estudo, porém, vamos nos deter no maior dos tipos rituais, onde todos os outros eram inseridos: o tabernáculo do deserto. É importante observar que, apesar de cada peça do tabernáculo apontar para Cristo, não podemos afirmar que cada uma delas, separadamente, é um tipo bíblico. $\mathrm{O}$ tabernáculo, como um todo, sim, é, declaradamente, um tipo de Cristo.

\section{a) O Tabernáculo}

Estudar o Tabernáculo é uma tarefa de extrema importância para a igreja dos dias atuais, para que possamos aprender o significado de cada uma das peças que formavam este santuário no deserto, sabendo que cada uma delas foi planejada por Deus, que recomendou a Moisés que as construísse conforme o modelo que Ele mesmo deu, pois havia uma mensagem e um exemplo a ser mostrado em cada uma delas.

Neste estudo podemos aprender mais sobre este santuário e a mensagem contida em cada detalhe do Tabernáculo,a respeito dos quais, afirmou o escritor aos Hebreus: "Os quais servem de exemplo e sombra das coisas celestiais, como Moisés divinamente foi avisado, estando já para acabar o Tabernáculo; porque foi dito: Olha, faze tudo conforme o modelo que no monte se to mostrou." (Hebreus 8.5).

\section{$\underline{\text { O local }}$}

A planta do Tabernáculo foi dada a Moisés no Monte Sinai. A sua construção determinou o inicio do cerimonial religioso entre o povo de Israel. Cerca de dois milhões de israelitas que haviam saído do Egito estavam ao pé do monte, onde Deus manifestou a sua glória a Moisés, entregou os 10 mandamentos e deu a ordem para construir cada peça, detalhadamente.

"Então disse o Senhor a Moisés: Sobe a mim ao monte, e fica lá: e dar-te-ei tabuas de pedra, e a lei, e os mandamentos que tenho escrito para ensinar.” (Ex 24.12).

\section{$\underline{\text { O Propósito }}$}

O Tabernáculo foi construído para que o Senhor fosse adorado pelo seu povo e para que estivesse sempre presente entre eles. A expressão divina foi: "E me farão um santuário, e habitarei no meio deles" (Ex 25.8).

\section{Os Materiais}

Os materiais utilizados eram duráveis, já que o Tabernáculo seria conduzido pelo deserto e as peças seriam montadas e desmontadas. Também foram utilizados materiais que estavam disponíveis na região. Os materiais preciosos foram trazidos do Egito, quando os filhos de Israel "saquearam" o povo egípcio, e ofertaram para a construção (Ex 3.21,22; $12.35,36 ; 25.1,2 ; 36.5-7)$. 


\section{- Madeira de Acácia (ou cetim):}

Era encontrada no deserto do Sinai e ao redor do Mar Vermelho. Era uma madeira dura e não destruída por insetos. Ela simboliza a humanidade de Cristo, sem aparência, nem formosura, mas não corrompida pelo pecado (SI 16.10). Cristo é chamado em Is 4.2 de "fruto da terra"

\section{- Bronze:}

Foi o metal escolhido para esta finalidade por ser altamente resistente a alta temperatura. $\mathrm{O}$ ponto de fusão do bronze e de $1.985^{\circ} \mathrm{C}$. Bronze é uma liga de cobre e zinco. Ele representa juízo, sofrimento ou julgamento (Dt 28.23; Dn 10.6; Ap 2.18; SI 89.14).

\section{- Prata}

É um símbolo da redenção (Zc 11.12; Mt 26.15,16). Ela representa o preço pago por Cristo como resgate dos pecadores. Quando era feita a contagem dos filhos de Israel, cada israelita pagava um resgate: meio siclo de prata. Este prego era igual para todos, pobres e ricos (Ex 30.11-16).

\section{- Ouro:}

Como metal precioso e nobre, o ouro representa a divindade. Ouro fala do céu, da glória de Deus (Ap 3.18; Jo 22.25; Dn 10.5).

\section{- Linho:}

O linho fino era fabricado no Egito. Era usado pela realeza e por pessoas de destaque. Ele fala de pureza e santidade (Ap 19.6-8,14 , Is 64.6; 59.21). Aponta para a retidão de Cristo, o cordeiro imaculado (I Jo 3.3-5).

\section{A Localização}

O Tabernáculo era o centro do acampamento e a partir dele era feita a organização das tribos. Ao Norte estavam as tribos de Dã, Aser e Naftali. Ao sul estavam as tribos de Rubem, Gade e Simeão. Ao leste estavam as tribos de Judá, Issacar e Zebulom. Ao oeste estavam a tribo de Efraim, Benjamim e Manassés.

As tendas dos levitas e sacerdotes eram armadas ao redor do Tabernáculo, na seguinte ordem: Ao norte os filhos de Merari, ao sul os filhos de Coate, a oeste os filhos de Gérson e a leste Moisés, Arão e os sacerdotes Nadabe, Abiú, Eleazar e Itamar (Nm 2 e 3).

\section{$\underline{\text { O Tabernáculo }}$}

Era uma tenda portátil, com uma armação de madeira, cercada por uma cerca, formando um pátio, que era de acesso exclusivo dos levitas e sacerdotes, que ministravam o serviço diário. 
Era formada por 60 estacas, sendo 20 em cada lado, sendo 10 na parte de trás e 10 na frente, com 5 côvados de altura (cerca de 2,5 m), cada, mantendo uma distância de 5 côvados entre si, unidas por um pano de linho puro. As estacas eram de bronze e tinham uma cobertura de prata, estando presas por uma corda de pêlos de cabras entrelaçados a uma peça de bronze, que era enterrada pela metade (I Pe 1.3; 1 Cor 15.17).

"Fareis também o pátio do Tabernáculo; ao lado do meio-dia, para o sul, o pátio tem cortinas de linho tino torcido; o comprimento de cada lado será de cem côvados. Também as suas vinte colunas e as suas vinte bases serão de cobre; os colchetes das colunas e as suas faixas serão de prata. Assim também do lado do norte as cortinas na largura serão de cem côvados de comprimento; e as suas vinte colunas e as sues vinte bases serão de cobre; os colchetes das colunas e as suas faixas serão de prata. E na largura do pátio do lado do ocidente haverá cortinas de cinquenta côvados; as suas colunas, dez, e as suas bases, dez. Semelhantemente, a largura do pátio do lado oriental, para o levante, será de cinquenta côvados, de maneira que haja quinze côvados de cortinas de um lado; suas colunas, três, e as suas bases, três; e quinze côvados de cortinas do outro lado; as suas colunas, três, e as suas bases, três.” (Ex 27.9-15).

A cerca separava o Tabernáculo do restante do arraial, impedindo que homens não habilitados tivessem acesso ao pátio. O linho puro fala da santidade de Deus, que afasta o pecado (Is 59.2). As estacas de bronze falam do juízo de Deus sobre Cristo para justificação e remissão, e o resultado dela foi a redenção do homem, mediante pagamento de um resgate, representado pela cobertura de prata. A corda que fixa esta estaca era de pelo de cabra, símbolo do pecado do homem, que foi expiado (Lv 16.5,20-22). O selo desta redenção foi a ressurreição de Cristo, representado pela peça de bronze fincada ao solo pela metade (I Pe 1.3; 1 Cor 15.17).

\section{$\underline{\text { A Porta }}$}

O único acesso ao pátio era pelo lado oriental, através da porta. Era formada por quatro estacas, com base de bronze e cobertura de prata como as da cerca, cobertas por um reposteiro de linho puro branco, pintado de azul, púrpura e carmesim.

"E a porta do pátio haverá uma coberta de vinte côvados, de pano azul, e púrpura, e carmesim, e linho fino torcido, de obra de bordador; as suas colunas, quatro, e as suas bases, quatro." (Ex 27.16).

A porta fala-nos que o único acesso ao Pai é através de Jesus (Jo 10.9). Ela estava no lado oriental do Tabernáculo, isto é, defronte ao nascente (Gn 3.24; Ez 43.1-5; Ap 22.16), que fala de Cristo como o Sol da Justiça (MI 4.2); defronte também à tribo de Judá, que aponta 
para Cristo como o Leão da Tribo de Judá (Ap 5.5). As 4 estacas falam do aspecto universal da graça (Tt 2.11; Jo 1.12; Rm 10.11,12; 3.21-24)

\section{As Cores}

1. Azul

Esta cor era extraída de um molusco. Ela fala do céu, pois é a cor celeste (Dt 22.12). Aponta para Cristo, que veio "do alto" (Jo 3.31).

\section{Carmesim (Vermelho)}

É descrito na Bíblia como referência ao pecado (Lv 14.4-6; Is 1.18; Nm 19.2,6). Ele fala de Cristo que, apesar de não ter cometido pecado, foi feito pecado por nós.

\section{Púrpura}

Era obtida ao misturar-se o azul e o carmesim ou escarlata. Era uma cor usada nas roupas dos ricos. Ela fala da realeza de Cristo (Dn 5.7; Lc 16.19; Mc 15.17,18). Aponta para Cristo como o Rei dos reis e Senhor dos senhores (Ap 19.16). Fala também de Cristo que, sendo do céu (azul), tomou sobre si os nossos pecados (carmesim).

\section{Branco}

Fala da pureza e santidade de Cristo (como no linho).

\section{O Altar de Bronze}

Era de madeira de acácia, revestido de bronze, medindo 5 × 5 x 3 côvados (cerca de $2,5 \times 2,5 \times 1,5 \mathrm{~m}$ ). Ali eram queimados todos os animais sacrificados ao Senhor. Era oco, com uma grade de bronze no meio, para sustentar as vítimas. Tinha 4 pontas e era suspenso em uma base de terra. O fogo aceso uma vez pelo Senhor (Lv 9.24) e deveria permanecer sempre aceso (Lv 6.13). Havia também outros instrumentos de bronze para apanhar as cinzas, limpar os animais, etc. Possuía duas varas laterais utilizadas para o transporte.

"Fareis também o altar de madeira de cetim; cinco côvados será o comprimento, e cinco côvados, a largura (será quadrado o altar), e três côvados, a sua altura. E fareis as suas pontas nos seus quatro cantos; as suas pontas serão uma só peça com o mesmo, e o cobrirás de cobre. Far-lhe-ás também as suas caldeirinhas, para recolher a sua cinza, e as suas pás, e as suas bacias, e os seus garfos, e os seus braseiros; todos os seus utensílios fareis de cobre. Farlhe-ás também um crivo de cobre em forma de rede, e fareis a esta rede quatro argolas de metal aos seus quatro cantos, e as poreis dentro do cerco do altar para baixo, de maneira que a rede chegue até ao meio do altar. Fareis também varais para o altar, varais de madeira de cetim, e os cobrirás de cobre. E os varais se meterão nas argolas, de maneira que os varais estejam de ambos os lados do altar quando for levado. Oco, de tábuas, o farás; como se to mostrou no monte, assim o farão." (Ex 27. 1-8). 
O altar de madeira da acácia fala de Cristo encarnado (Is 53.2) e humilhado (Fp 2.7,8), que foi crucificado por nós. O bronze fala do juízo de Deus sobre Ele, por causa dos nossos pecados (II Cor 5.21). Os chifres, símbolo de poder, falam do poder redentor da morte de Cristo (Ap 5.6). Ele foi preso a cruz, assim como as vítimas do holocausto eram amarradas às pontas do altar (SI 118.27). O animal oferecido era suspenso na grade, assim como Cristo foi erguido na cruz (Lv 9.22b; Jo 3.14,15).

As cinzas eram símbolo de humilhação (Gn 18.27; Jo 42.6) e apontam para a humilhação de Cristo (Fp 2.7,8; Mt 27.39-44). Estas cinzas eram apanhadas e depositadas em um local limpo, fora do arraial ( $\operatorname{lv} 6.10,11)$, assim como Cristo foi colocado em um sepulcro novo (Jo 19.41) e morto fora da cidade (Hb 13.11-13). A vítima era oferecida em sacrifício, assim como Cristo, o cordeiro de Deus (GI 5.24; Rm 12.2; GI 2.20). O fogo que queimava a vitima é símbolo do juízo de Deus (Lv 6.12,13; 16.12,13; 10.1-3; Jz 6.21; Gn 19.24; Hb 12.28,29; Ez 39.6; Nm 11.1).

\section{A Pia de Bonze}

Era uma bacia posta sobre uma base, onde era armazenada água para uso dos sacerdotes. Não foram especificadas as suas medidas, nem o modo como era transportada. Ela foi construída com o bronze dos espelhos das mulheres (Ex 38.8). Os sacerdotes lavavam as mãos e os pés na pia antes e depois de entrar no santuário.

"Farás também uma pia de cobre com a sua base de cobre, para lavar, e a porás entre a tenda da congregação e o altar e deitarás água nela. E Arão e seus filhos nela lavará as suas mãos e os seus pés. " Lv 30.18,19

A pia estava colocada entre o altar e o santuário. O altar fala da redenção e a pia de purificação, assim como a santificação é o processo que sucede à experiência da salvação. No altar o crente é colocado em Cristo, enquanto que na pia ele mantém-se com Cristo.

\section{A Tenda da Congregação}

Também chamada de Santuário, era uma tenda formada de tábuas de madeira de acácia, revestidas de ouro. Ao todo eram 48 tábuas, sendo 20 de cada lado, 6 no fundo e 2 nos cantos. Estas tábuas estavam fixadas de duas em duas em uma base de prata, de cerca de 43 $\mathrm{Kg}$ e unidas por travas horizontais. Haviam cortinas de linho, com querubins bordados, que eram cobertas por 3 camadas de couro e pêlo. Um reposteiro das mesmas cores do portão estava na entrada sobre 5 colunas de bronze e um véu dividia os dois compartimentos: o lugar santo e o santo dos santos ou lugar santíssimo.

“Também fez, de madeira de acácia, tábuas levantadas para o tabernáculo, que foram colocadas verticalmente. O comprimento de cada tábua era de dez côvados, e a largura de um 
côvado e meio. Cada tábua tinha duas cavilhas pregadas uma a outra; assim fez com todas as tábuas do tabernáculo.” (Ex 36.20-22).

O corpo do santuário era erguido com tábuas de madeira. Isto fala de Cristo, que teve corpo humano, e também fala da igreja, o corpo místico de Cristo. As tábuas eram iguais; foram cortadas, aplainadas e preparadas e passaram a ter as mesmas medidas, o que aponta para a igualdade no corpo e Cristo, onde não há acepção de pessoas (Cl 3.11; Rm 2.11; At 10.34,35). Estas tábuas foram revestidas de ouro, que representa a glória de Deus (Ap 5.10; I Pe 2.9; II Ts 2.13,14), na qual fomos feitos sacerdotes (Rm 8.30, Ef 1.11-14). As tábuas estavam fixas no solo sobre bases de prata, que representam o preço do resgate pago para comprar a igreja (Ap 5.9; I Co 6.20; 3.11). Elas estavam unidas umas às outras por travessas também de madeira, revestidas de ouro. Isto fala da união que deve haver no corpo de Cristo (S1 133; Jo 17.22,23).

Por sobre as tábuas eram colocadas cortinas de linho puro, que falam da santidade necessária à igreja (I Pe 1.15). Os querubins bordados nas cortinas são os guardiões da santidade e da glória de Deus (I Sm 4.4; Gn 3.24; Ez 10). As cortinas cobriam o santuário e ficavam a 1 côvado do solo, sem tocá-lo. Elas representam o Cristo ressurreto, que não tocará o solo, em sua segunda vinda.

\section{A Mesa dos Pães}

Dentro do santuário, à direita de quem entrava, estava uma mesa de madeira de acácia, revestida de ouro, com uma moldura, em forme de anteparo e duas varas laterais, presas em argolas de ouro, para ser transportada, medindo 2 x 1 x 1,5 côvados. Em cima dela estavam duas pilhas de 6 pães, e um depósito de incenso. Eram os pães da proposição, ou presença, que deveriam ser substituídos a cada sábado.

"Também farás uma mesa de madeira de cetim; o seu comprimento será de dois côvados, e a sua largura dum cavado, e a sua altura de um côvado e meio, e cobri-la-ás com ouro puro: também lhe farás uma coma de ouro ao redor. Também lhe farás uma moldura ao redor, da largura duma mão, e lhe farás uma coroa de ouro ao redor da moldura. Também lhe farás quatro argolas de ouro; e porás as argolas aos quatro cantos, que estão nos seus quatro pés." (Ex 25.23-26).

O pão é um gênero de primeira necessidade. Ele é servido na mesa do rico e do pobre todos os dias e em todos os países. Ele fala de Cristo, o pão da vida (Jo 6.35, 51-58) e da sua carne (Jo 6.47-51). Isto lembra-nos a Santa Ceia, o memorial da comunhão, quando todos sentamos à mesa do Senhor para comer o pão (I Cor 11.23,24). Os pães eram do mesmo tamanho, o que fala da unidade na comunhão (Rm 12.5). Eram pães asmos, isto é, sem 
fermento, o que fala da santificação necessária aquele que se senta à mesa do Senhor (I Cor $5.6-8)$.

Os doze pães representam as 12 tribos de Israel, isto é, todo o povo, e deveria ser comido pelos sacerdotes, os representantes do povo. Eles lembravam a cada israelita sua constante dependência da presença de Deus. O pão era feito de trigo, que era queimado e moído (Jo 12.24,27,31-33). A mesa possuía uma moldura da largura de uma mão, para evitar que os pães caíssem, o que fala da proteção de Cristo. Sobre os pães era colocado um vasilhame com incenso; um perfume utilizado apenas para este fim. Este incenso é um tipo de Cristo, sempre presente a mesa (Ct 1.12; II Cor 2.14,15).

\section{O Candelabro}

Do lado esquerdo do santuário, em frente à mesa, estava o candelabro ou candeeiro, chamado em hebraico menorah. Ele era a única fonte de luz dentro do santuário, que não possuía janelas. O candelabro era de ouro puro batido, tendo uma haste central, presa a uma base e seis hastes laterais.

As sete lâmpadas estavam acesas ininterruptamente (Lv 24.2) e eram abastecidas pela manhã e tarde. Havia espevitadores de ouro especialmente para aparar o pavio das lâmpadas. Não são especificadas as suas medidas, nem como era transportado.

"Também farás um castiçal de ouro puro; de ouro batido se fará este castiçal: o seu pé, as suas canas, as suas copas, as suas maçãs, e as suas flores serão do mesmo. E dos seus lados sairão seis canas: três canas do castiçal dum lado dele, e três canas do castiçal do outro lado dele". (Ex 25.31,32).

O candelabro fala de Cristo, a luz do mundo (Jo 8.12; 9.5; 1.4-9). Ele e a haste ou castiçal principal, pois é a única luz que dissipa as trevas do pecado. As hastes laterais são a igreja. São seis hastes e este número representa o homem (Ap 21.15-17; 13.18). Elas falam que somos luz do mundo (Mt 5.14-16; 1Ts 5.51), andamos na luz (I Jo 1.7) e precisamos dar testemunho de vida (Ef 5.8).

\section{O Altar do Incenso}

Defronte ao véu estava a peça mais alta do santuário: o altar do incenso. Era uma peça de madeira de acácia, revestida de ouro, que media 2 × 1 x 2 côvados. Ele também possuía varas laterais para o transporte, também revestidas de ouro. Sobre o altar do incenso era queimado um incenso, cuja fórmula foi dada por Deus, para ser utilizado exclusivamente neste serviço.

\section{O Incenso}


Era confeccionado com três substâncias aromáticas: o estoraque, uma substância extraída de uma planta chamada benjoeiro, que goteja espontaneamente uma substância aromática. Isto fala da espontaneidade da nossa oração e interseção (SI 100.2; Fp 1.4); a onicha, extraído de um molusco chamado strombus, encontrado no fundo do mar, que fala da profundidade do nosso relacionamento com Deus em oração (Jr 29.13); e o gálbano, extraído do esmagamento de galhos e folhas de uma planta da mesma família da erva-doce, que fala do quebrantamento que precisa haver em nós quando nos dirigimos a Deus (SI 51.7). Era adicionada à fórmula uma resina branca, que era o próprio incenso e sal, que fala da nossa temperança $(\mathrm{Cl}$ 4.6).

\section{O Véu e o Santo dos Santos}

Separando o lugar santo do lugar santíssimo havia um véu, de linho puro, com querubins bordados.

"Depois farás um véu de azul, e púrpura, e carmesim, e de linho fino torcido; com querubins de obra prima se fará. E o porás sobre quatro colunas de madeira de cetim, cobertas de ouro: seus colchetes serão de ouro, sobre quatro bases de prata." (Ex 26.31,32).

\section{A Arca do Testemunho}

O único móvel dentro do santo dos santos era uma arca de madeira de acácia, revestida de ouro, medindo 2,5 x 1,5 x 1,5 côvados. Assim como outras peças, a arca possuía varas laterais para o transporte. Dentro da arca estavam as tabuas da lei, entregues a Moisés no Monte Sinai, a vara de Arão que floresceu e um vaso de ouro contendo uma porção de maná.

\section{O Propiciatório}

A tampa da arca era uma peça única de ouro puro batido onde estavam dois querubins, um de frente para o outro, com as asas para a frente e os rostos voltados para baixo.

A arca era o objeto mais sagrado do Tabernáculo; era o símbolo da presença de Deus entre o povo. Ela desempenhou um papel importante, em muitas ocasiões, a frente do povo (Nm 10.33; Js 3.4; 6). Era o símbolo do pacto entre Deus e os filhos de Israel. Ela foi a primeira peça cuja construção foi ordenada por Deus. Isto fala que Deus quer trabalhar no homem de dentro para fora e que e a presença de Deus no interior do homem que vai fazer a diferença na vida deste.

As tábuas da lei que estavam no interior da arca falam da aliança de Deus com os homens ( $\mathrm{Hb} 8.6,7,13)$. O maná, como alimento fornecido diariamente, fala da fidelidade e do cuidado de Deus (2Tm 2.13). A vara de Arão fala da autoridade dada por Deus (Rm 13.17). O propiciatório representa o trono de Deus, guardado pelos querubins (S1 99.1). Deus fala 
com o povo daquele lugar (Ex 25.22). O povo estaria sendo levado à presença de Deus pelo sacerdote. Isto aponta para Cristo, que foi feito a nossa propiciação ( $R m$ 3.25; 1Jo 2.2).

\section{CONSIDERAÇÕES FINAIS}

Concluindo o estudo da Tipologia Bíblica, podemos verificar a soberania de Deus, escrevendo profecias através de pessoas, objetos e eventos, e as cumprindo na pessoa de Cristo, e a perfeita relação entre o Antigo e o Novo Testamento, apresentado o tipo e o antítipo, em perfeita harmonia. Além disto, podemos observar a riqueza de material e significado que o Antigo Testamento nos dá, a fim de nos ensinar profundas verdades espirituais.

Não devemos abrir mão desta riqueza de significado que os tipos bíblicos nos mostram, tendo o cuidado de não ferir os princípios de interpretação da Bíblia, evitando a alegorização dos tipos bíblicos e verificando o significado e a relação tipológica que a própria Bíblia nos apresenta.

\section{BIBLIOGRAFIA}

MELO, Joel Leitão de, Sombras, Tipos e Mistérios da Bíblia, CPAD, Rio de Janeiro, $7^{\mathrm{a}}$ edição, 1997.

ZUCK, Roy B., A Interpretação Bíblica: meios de descobrir a verdade da Bíblia, Edições Vida Nova, São Paulo, $1^{\text {a }}$ edição, 1994.

HABERSHON, Ada R., Manual de Tipologia Bíblica: como reconhecer e interpretar símbolos, tipos e alegorias das Escrituras Sagradas, Editora Vida, São Paulo, 2003.

GRONINGEN, Gerard van, Revelação Messiânica no Antigo Testamento, Editora Cultura Cristã, São Paulo, $2^{a}$ edição, 2003.

GREIDANUS, Sidney, Pregando Cristo a partir do Antigo Testamento, Editora Cultura Cristã, São Paulo, $1^{a}$ edição, 2006.

PAGANELLI, Magno, Onde Estava o Cristo: identificando Cristo nas figuras do Antigo Testamento, Editora Arte Editorial, São Paulo, 1ª edição, 2003.

SPRECHER, Alvin, Estudo Devocional do Tabernáculo no Deserto, CPAD, Rio de Janeiro, $1^{\mathrm{a}}$ edição, 2002.

GILBERT, Floyd Lee, A Pessoa de Cristo no Tabernáculo, Editora Fiel, São José dos Campos-SP, $4^{\text {a }}$ edição, 1999. 
CONNER, Kevin J., Os Segredos do Tabernáculo de Moisés, Editora Atos, Belo HorizonteMG, $1^{\text {a }}$ edição, 2004.

CONNER, Kevin J., Os Segredos do Tabernáculo de Davi, Editora Atos, Belo Horizonte-MG, $1^{\mathrm{a}}$ edição, 2004.

HAMILTON, Victor P., Manual do Pentateuco, CPAD. Rio de Janeiro, $1^{\text {a }}$ edição, 2006. 